
World Ecology

\title{
Urban forest in China: Development patterns, influencing factors and research prospects
}

\section{Feng Li , Rusong Wang , Xusheng Liu \& Xiaoli Zhang}

To cite this article: Feng Li , Rusong Wang , Xusheng Liu \& Xiaoli Zhang (2005) Urban forest in China: Development patterns, influencing factors and research prospects, International Journal of Sustainable Development \& World Ecology, 12:2, 197-204, DOI: $10.1080 / 13504500509469630$

To link to this article: http://dx.doi.org/10.1080/13504500509469630

\section{曲 Published online: 24 Nov 2009.}

\section{Submit your article to this journal $\square$}

Џ Article views: 125

Q View related articles ¿

Citing articles: 10 View citing articles 5 


\title{
Urban forest in China: Development patterns, influencing factors and research prospects
}

\author{
Feng Li ${ }^{1}$, Rusong Wang ${ }^{1}$, Xusheng Liu ${ }^{2}$ and Xiaoli Zhang ${ }^{3}$ \\ ${ }^{1}$ Key Lab of Systems Ecology, Research Center for Eco-Environmental Sciences, Chinese \\ Academy of Sciences, Beijing, China \\ ${ }^{2}$ Chinese Academy of Forest Inventory and Planning, State Forestry Administration, Beijing, \\ China \\ ${ }^{3}$ Resource and Environment College, Beijing Forestry University, Beijing, China
}

Key words: Urban forest, green space, development pattern, urban planning, management, China

\begin{abstract}
SUMMARY
Urban forest is a very important part of urban ecosystems and provides significant ecosystem services. It benefits urban communities environmentally, aesthetically, recreationally and economically. This article reviews the development status, development patterns and influencing factors of urban forest in China. There are four typical development patterns of urban forest in China: the forest city, garden city, ecological economics and forest greenbelt. Social, climatic, economic and other factors influence urban forest development in China. Social factors include government behaviour, laws and regulations, science and technology, education and culture, public awareness and participation, ecological planning and management. Climatic factors include rainfall, temperature and sunlight. Economic factors include urban economic level and funding for urban forest. In future, government, NGOs and the private sector should be considered more in the planning and management of urban forest. The social, climatic and economic factors should be taken into account when improving urban forest management. Research on urban forest from the academic and the management viewpoint should be strengthened. This can improve the development and management of urban forest in China and in other developing countries.
\end{abstract}

\section{INTRODUCTION}

The world is becoming increasingly urban and, by 2005 , some $65 \%$ of the world population is expected to be urban (Schell and Ulijaszek 1999). Urbanization promotes the rapid development of society and economy but, at the same time, it also brings many problems, such as population centralization, traffic jams, housing shortages, resource shortages and biodiversity reduction, heat island effects, and air, noise and water pollution. With rapid urbanization and serious environmental problems, people are increasingly realizing the significance of urban forest in improving the urban environment. Many countries have already decided that urban forestry is an important strategy for

Correspondence: Feng Li, Key Lab of Systems Ecology, Research Center for Eco-Environmental Sciences, Chinese Academy of Sciences PO Box 2871, Beijing 100085, China. Email: lifengxus@yahoo.com.cn 
urban sustainable development (Attwell 2000). Increasingly, ecological security has already become an important component of nationa security. Urban forest may be regarded as a key indicator for measuring cultural progress and sustainable development of a city.

A city is a kind of social-economic-natural complex ecosystem, dominated by humans (Ma and Wang 1984; Wang et al. 2001). Urban forest is an important natural or artificial component of the complex urban ecosystem. It has significant ecosystem services, defined as the benefits the human population derives, directly or indirectly, from ecosystem functions (Costanza et al. 1997). Urban forest has ecological effects, contributes to public health and increases the quality of life of urban citizens, e.g. offsetting carbon emissions and producing oxygen (Jo 2002), purifying air and water regulating the microclimate, reducing noise (Bolund and Hunhammar 1999), protecting soil and water (Jim 2001), maintaining biodiversity (Attwell 2000), and having recreational, cultural and social values (Savard et al. 2000; Tarrant and Cordell 2002). Furthermore, urban forest has economic effects, including a statistically significan effect on the price of houses in close proximity to those resources (Bolitzer and Netusil 2000; Luttik 2000). Thus, urban forest benefits urban communities environmentally, aesthetically, recreationally and economically (Li and Wang 2003).

The objective of this paper is to review the development status, development patterns and influencing factors of urban forest in China; research prospects are also advanced.

\section{WHAT IS URBAN FOREST}

There are many definitions of urban forest. Differ ent experts have different concepts of urban forest resulting from different understandings and research focus. Up to now, there is no widely accepted definition of urban forest, a concept first put forward by Erik Jorgensen in Canada in 1965 (Grey and Deneke 1986). Urban forest is most often defined as the cultivation and management of trees for their present and potential contribution to the physiological, sociological and economic well-being of the urban society (Jorgensen 1974; Rydberg and Falck 2000). Urban forests are generally considered to include the total tree population within the entire area influenced and utilized by the urban population (Collins 1995; Grey 1996). In central Europe, urban forest refers to individual trees, treelines and man-made parks (Tyrv nen 1997). In Sweden, the definition of urban forests used to be restricted to only urban fringe forests (Hultman 1979; Rydberg and Falck 2000). In China, urban forest is different not only from urban gardens, but also from traditional forestry. It is regarded as a part of urban social and economic development. The goal of urban forests is decided by the demands of urban social, economic and ecological development. Urban forest should conform to urban spatial distribution, supporting urban sustainable development, improving the urban environment and increasing the level of urban culture and welfare (Zhang 1996).

\section{STATUS OF URBAN FOREST IN CHINA}

Research on urban forestry began later in China, and Gao (1984) published Urban Forest in the Taiwan Province of China. At the same time, the concept and research methods of urban forest were introduced from other countries into China (Wang 1995). In 1992, the first symposium on urban forests was held in Tianjin, China with more than 50 attendees from 12 cities. They discussed concepts, content, planning and development measures of urban forests. They proposed that multi-functional and high-benefit urban forest should be developed in China according to the demands of urban and economic development (China Forestry Institute 1993). The China Urban Forest Committee was subsequently set up by the China Forestry Institute in 1994 to promote the urban forest development in China. The Action plan of forestry, twenty-first century agenda in China was established by the China Forestry Ministry in 1995. This defined the basis, goals and action of urban forest development in China and pointed out that developing urban forest, increasing public green space and improving the urban environment were primary tasks for urban sustainable development (China Forestry Ministry 1995)

An international symposium on urban forest and eco-city was held in Shanghai in September, 2002. This focused on five aspects of urban forests: theory and practice, features and roles in the planning and design of an eco-city, case studies of urban afforestation, management and urban trees, and methods for evaluation. 
At present, many cities in China have put forward strategic goals for urban forest development Up to now, the average greening cover in built-up areas of cities in China is $27.6 \%$, and the average public green space per person is $6.5 \mathrm{~m}^{2}$. Among big cities, Shenzhen has the largest public green space per person, $34.3 \mathrm{~m}^{2}$ and Zhuhai has the largest greening cover of $43.5 \%$.

Although great achievements have been made in urban forest development in China, there are still some problems:

- Lack of strategic and detailed planning in many cities;

- Inappropriate forest community structure;

- Lack of funding;

- Poor forest management; and

- Human invasion of urban forests in many developing cities.

\section{TYPE, STRUCTURE AND FUNCTION OF URBAN FOREST IN CHINA}

\section{Classifications of urban forest}

Urban forest varies considerably according to the criteria chosen (Li and Liu 2002):

1. Location: built-up area forest, suburban forest and outskirt forest.

2. Function: urban productive forest, environmental protection forest, shelter forest, historical and cultural forest, and tourism forest.

3. Use: timber forest, shelter forest, commercia forest, firewood forest and forest for special purposes. These five types often appear in both urban and rural areas, but their quantity and location is different due to their different functions.

4. Other criteria: urban forest can be planned and designed as a special area in light of urban demands, such as greenbelts, greenways and green wedges.

\section{Structure and function of urban forest}

The structure and function of urban forests varies with location, as noted above.

1. Built-up area forest includes trees, shrubs, flowers and grasses. It is usually found in public parks, gardens and roadsides. It has the function of providing comfortable habitation and maintaining physical and mental health. Vertical greening, such as roof gardens and wall greening, should be adopted to reduce the heat island effect in build-up areas.

2. Suburb forest is located between the urban centre and its outskirts and includes tourism, shelter, commercial, timber and firewood forests. It has the function of maintaining balance in an urban ecosystem, providing tourism opportunities and many forest products. It also offers services for living organisms, culture and production in built-up areas.

3. Outskirt forest is located in the outer parts of a city and is composed of forest parks, greenbelts, greenways, etc. It is mainly timber, water conserving and shelter forest. It can shape good urban landscape form, improve the urban environment, provide areas for the urban population, and prevent urban excessive sprawl. Outskirt forest should be connected with neighbourhood green space to form an ecological network that is useful for people and wildlife.

\section{DEVELOPMENT PATTERNS OF URBAN FOREST IN CHINA}

There are more than 660 cities in China with varying patterns of urban forest depending on the prevailing urban conditions. An urban forest development pattern should be defined according to geography, urban characteristics, city size, economic development level and special environment demands of a city. There are four typical development patterns in China:Forest City, Garden City, Ecological Economics and Forest Greenbelt.

\section{Forest City}

The Forest City pattern is where forests are brought into city and city is located in forests. It is regarded as the most economic and effective means of improving urban environmental quality. Currently, there are three Forest Cities in China: Changchun in Jilin Province, Fuxin in Liaoning Province and Loudi in Hunan Province.

The first demonstration Forest City construction was at Changchun, begun in 1988. Presently, the green coverage in the built-up area of Changchun is 
$41 \%$; the public green space per person is $10 \mathrm{~m}^{2}$. It progressed according to three green sections (greenway, satellite town greening and landscape greening between the urban and rural area) and ten key greening projects. Five of the greening projects have been undertaken on deserted hills, river and reservoirs, farmland shelter forest networks, villages and boundary protection forests in the urban outer zones.

\section{Garden City}

A Garden City is an urban development pattern that is based on natural and geographic features, distributional character and social economic status. It is evaluated and approved according to ten criteria established by the China Construction Ministry. By the end of 2000, 20 cities had been selected: Beijing, Hefei, Zhuhai, Dalian, Hangzhou, Shengzhen, Maanshan, Weihai, Zhongshan, Nanjing, Nanning, Xiamen, Qingdao, Puyang, Shiyan, Foshan, Sanming, Qinghuangdao, Yantai and Shanghai (Pudong district).

\section{Ecological Economics}

The Ecological Economics pattern requires full recognition of the ecological benefits of urban forest and, at the same time, the need for economic benefits. Tianjin City and Quwo County in Shanxi Province are symbols of this pattern. In Tianjin, a ton of wood for newspaper is produced every year by using planting techniques of high density and short rotation forestry. This pattern not only enhances forest coverage of urban and rural area and improves the urban environment, but also brings great economic benefits (Wu 1994).

\section{Forest Greenbelt}

The Forest Greenbelt pattern involves large-scale forest greenbelt, planned and constructed around an urban area in order to limit excessive urban extension and to improve the urban environment (Figure 1). It also can produce great economic benefit for suburban farmers . Tianjin, Harbin, Benxi, Guiyang, Jinan, Hefei, Xi'an, Beijing and Shanghai are typical of this pattern.

The Forest Greenbelt in Tianjin was constructed between 1987 and 1989, and was the largest greenbelt at that time in China. The forest park around the urban area in Benxi in Liaoning Province was built between 1989 and 1991, and was the largest forest park at that time in China. The forest protection greenbelt was created in Harbin between 1993 and 1998. An urban Forest Greenbelt in Guiyang was also constructed and laws and detailed regulations were established. Now, urban Forest Greenbelt is under construction in Beijing and Shanghai, with the aim of harmonizing the relationship between urban development and environment, improving natural ecosystem services for people, and promoting urban sustainable development.

\section{FACTORS INFLUENCING URBAN FOREST DEVELOPMENT IN CHINA}

Cong (2000) and Li (2001) analyzed the relationship between urban forest and urban climate, land, economic and social factors of all cities in China using factor analysis. They showed that social factors were the primary influence on urban greening, followed by climate factors, and economic factors. Other factors influencing urban forest include land resources, soil thickness and quality.

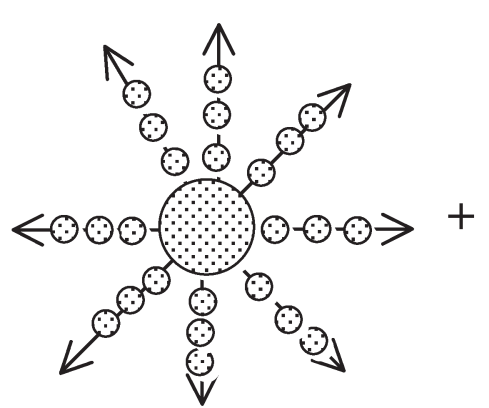

Traffic axis with settlement nodes

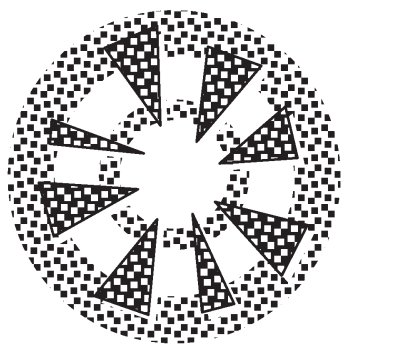

Greenbelts and green wedges

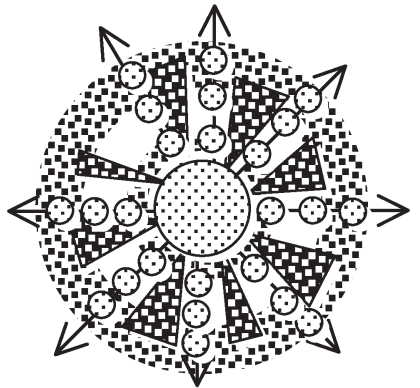

Forest Greenbelt pattern

Figure 1 Forest Greenbelt pattern illustration for urban development 


\section{Social factors}

Social factors have the largest influence on urban forest development. They are wide ranging and very complicated, mainly including government behaviour, laws and regulations, science and technology, education and culture, public awareness and participation, ecological planning and management.

\section{Government behaviour}

Government behaviour includes decision-making, control, intervention and funding. It has a macroregulation role in urban forest development. Due to the different institutional systems and interests, urban forest often involves many conflicts between different departments, the part and the whole, the short term and the long term. So, urban forest management should be controlled within the macro-regulation of government. Urban forest is a form of public enterprise, so the main source of funding should be the government and society as a whole.

\section{Laws and regulations}

Improved laws and regulations are important guarantees for urban forest. Up to now, some laws and rules have been established in China, such as the forest law, rules of urban greening, law of environment protection and so on. But in some cities of China, because laws and regulations are not strictly enforced and people's law awareness is poor, the phenomena of invading and destroying urban forest often takes place (Ye 1997). Therefore, supervision should be improved and law enforcement should be strengthened.

\section{Science and technology}

Science and technology can increase forest produc tivity and are developing very fast. We must depend on them to achieve the goal of investing less money and gaining more benefits from urban forest Technologies such as remote sensing, geographic information systems, global position systems, and biological engineering technology for urban forests are a promising prospect. We should extend the application of existing science research and accelerate it to enhance practical productivity.

\section{Education and culture}

Many problems of urban forest management are caused by inappropriate human activites, especially insufficient ecological awareness of planners and policy-makers (An and Weisman 1994). In order to move toward solving this problem, it is necessary to implement eco-education and demonstrations aimed particularly at policy-makers, entrepreneurs, scientists, ordinary citizens and students. Means of education include classroom education, experimental stimulation, media propaganda, field experience, case demonstrations and public participation (Wang et al., 2001). Eco-culture will influence people's value systems, production methods, consumption patterns, and policymaking behavior. This is very helpful for urban forest development.

\section{Public awareness and participation}

These are the key factors that decide the success or failure of management of urban forest. Enhancing public awareness is highly significant in aligning human activities with natural ecological processes. People should realize the importance of urban forest for better living quality and voluntarily take a full part in the preservation and management of urban forest. People's understanding of the importance of ecosystem services of the urban forest should be improved through propaganda and eco-education. More incentives are required so that developers can more easily recognize that their voluntary participation in preserving and allocating urban forest is in their best interest.

\section{Ecological planning and management}

Ecological planning and management of urban forest is of the utmost importance for future urban development. Ecological planning has to analyze, simulate and design all kinds of ecological relationships within artificial ecosystems using principles and methods of ecology and systems science, with the aim of improving ecosystem services and promoting sustainable development between humans and nature (Wang et al. 2001). Ecological management involves management of the urban ecosystem using ecosystem theory. Urban forest should be planned and designed according to the current status and the demands of urban sustainable 
development. Its planning and management must proceed hand in hand with surrounding regional land-use planning (Shafer 1999).

\section{Climatic factors}

Climatic factors include rainfall, temperature and sunlight, all of which are important factors influencing urban forest development. In cities of Northwest China, there is less than $400 \mathrm{~mm}$ of rain per year. These cities belong to semi-arid, arid, extreme arid climate areas, so it is very difficult for many trees to grow healthily without additional funding and human participation. In the cities of Southwest China, rainfall is approximately $1000 \mathrm{~mm}$ per year and falls within the semi humid, humid, extreme humid climate area, making it suitable for trees to grow. The climatic factors are not easy to change, so other measures should be considered to improve urban forest status, such as tree species selection, rainwater collection, and management improvement.

\section{Economic factors}

Urban economies

Generally speaking, there is sufficient money for urban forest construction in rich cities. The economic level of cities in East China is high, as in Shanghai, Guangzhou, Shengzhen and Dalian Urban forest develops rapidly in these cities and great achievements have been made (Zhang 1997) Conversely, the economic level of cities in Middle and West North China is low, so urban forest develops slowly in these cities (Table 1). Proved by practice, urban forest can accelerate the development of urban economy because of improved environment and more investors, and vice versa.

\section{Funding for urban forest}

Funding for urban forest is an important factor in influencing urban forest development. At present, funding for urban forest construction is inadequate in China, most comes from the government. Urban forest benefits the public, so funding should come from society through different channels. In future, a compensation mechanism based on ecological services of urban forest must be established to radically resolve the shortage of funding.

\section{Other factors}

There are yet other factors influencing urban forest development, such as land resources, soil thickness and quality and so on. Urban forest grows on the land, so land resource restricts the urban forest development. During urban development, the original soil is often buried, truncated, removed, compacted and contaminated, thus damaging the composition and properties of the soil (Blume 1989; Craul 1992). All these are harmful to plant growth in urban areas. Appropriate measures should be adopted to improve the land condition for urban vegetation.

\section{CONCLUSIONS}

This paper reviews the development status, patterns and influencing factors of urban forest in China. Social, climatic, economic and other factors play an important role in the planning and management of urban forest (Landelma et al. 2000). In particular, stakeholders and the public play a significant role in the decision-making process about how urban forest should be planned and managed. The improvement of stakeholder participation and coordination of planning institutions is crucial for success. Most governments of cities in China have

Table 1 Comparison between urban greening and economic development of cities in China

\begin{tabular}{lccc}
\hline Cities & $\begin{array}{c}\text { Gross Domestic Production } \\
(\text { GDP) per person }(C N Y)\end{array}$ & $\begin{array}{c}\text { Green space per person }\left(\mathrm{m}^{2}\right) \\
\text { in the built-up area }\end{array}$ & $\begin{array}{c}\text { Greening coverage in the } \\
\text { built-up area }(\%)\end{array}$ \\
\hline Cities in East China & 11392 & 25.2 & 30.4 \\
Cities in Middle China & 6921 & 20.1 & 29.7 \\
Cities in West China & 6397 & 11.3 & 22.1
\end{tabular}

Source: The urban social and economic survey team of the national statistical bureau. (2001). Chinese urban statistical annual 2000. (Beijing: Chinese Statistical Press) (in Chinese) 
already realized this problem. In future, government, NGOs and the private sector should give more consideration to planning and management of urban forest (Kajembe et al. 2003; Polansky 2003). The social, climatic and economic factors should be taken into account when improving urban forest management practices. A more complete understanding of ecosystem services of urban forests and extensive active participation of the public should be considered in develop ment of the eco-city to achieve long-term sustainability.

More work needs to be done in research on urban forest. It is particularly important to enhance ecosystem services of urban forest in China. From the academic viewpoint, further research on urban forest needs to concentrate on:

- Development of a comprehensive index for evaluation;

- Quantitative and qualitative assessment of ecosystem services, including economic evaluation: a green gross domestic product;

- Spatial analysis of ecosystem services;

- Evaluating the relationship between ecosystem services and water demand for normal tree growth

\section{REFERENCES}

An L and Weisman J. Ecological analysis of Beijing: present situation, trends, and suggestion. In Wang RS and Lu YL (eds), Urban ecological development: research and application. Beijing: China Environmental Science Press; 1994:141-57

Attwell K. Urban land resource and urban planting case studies from Denmark. Landscape and Urban Planning 2000;52:145-63

Blume H P. Classification of soils in urban agglomerations. Catena 1989;16(3):269-75

Bolitzer B and Netusil NR. The impact of open spaces on property values in Portland, Oregon. Journal of Environmental Management 2000;59:185-93

Bolund P and Hunhammar S. Ecosystem services in urban areas. Ecological Economics 1999;29:293-301

China Forestry Institute. Urban forest - the first symposium of urban forest in 1992 in China. Beijing: Chin Forestry Press (in Chinese; 1993)

China Forestry Ministry. Action plan of forestry, 21 century agenda in China. (in Chinese); 1995:56-8

Collins KD. A strategy for urban forestry in Ireland. Dublin: ECO Report; 1995
For the management of urban forest in Beijing, it is particularly important to obtain more information on:

- Developing an effective institutional system for the management;

- Establishing more effective measures and regulations for forest preservation;

- Instituting ecological education and demonstration projects for protecting urban forests and other open space;

- Lastly, and possibly most important, creating a positive and balanced relationship between economic development and environment protection.

Work in all of these fields is important to improve the development and management of urban forest not only in China but also in other parts of the world.

\section{ACKNOWLEDGEMENTS}

This research is financially supported by the Knowledge Innovation Project of the Chinese Academy of Sciences (No. KZCX3-SW-424). We would like to thank Juergen Paulussen for drawing the Figure and correcting the English.

Cong RC. The research of evaluating index system and type classification of urban forest in China. Postdoctoral report (in Chinese); 2000

Costanza R, d'Arge R, de Groot R, Farber S, Grasso M, Hannon B, Laskin R, Sutton P and van den Belt M. The value of the world ecosystem services and natural capital. Nature 1997;387(15):253-60

Craul PJ. Urban soil in landscape design. 396 pp. New York: John Wiley and Sons; 1992

Gao Q. Urban forest. Taipei: Translation and Edition Press; 1984:1-6

Grey GW. The urban forest: comprehensive management. New York: Wiley; 1996

Grey GW and Deneke FJ. Urban forestry. New York: Wiley; 1986

Hultman S-G. Interpretation for recreation and wood production in urban forests. Arboriculture Journal $1979 \cdot 3 \cdot 483-9$

Jim CY. Managing urban trees and their soil envelopes in a contiguously developed city environment. Environmental Management 2001;28(6):819-32 
Jo HK. Impacts of urban greenspace on offsetting carbon emissions for middle Korea. Journal of Environmental Management 2002;64:115-26

Jorgensen E. Towards an urban forestry concept. Prepared for the 10th Commonwealth Forestry Conference, Ottawa, Canada; 1974

Kajembe GC, Luoga EJ, Kijazi MS and Mwaipopo CS. The role of traditional institutions in the conservation of forest resource in East Usambara, Tanzania. The International Journal of Sustainable Development and World Ecology 2003;10 (2) 101-7

Landelma R, Salminen P and Hokkanen J. Using multicriteria methods in environmental planning and management. Environmental Managemen 2000;26(6):595-605

$\mathrm{Li} \mathrm{F}$. The research of evaluating index system and type classification of urban forest in West China. Masters Thesis, Chinese Academy of Forestry, Beijing, China (in Chinese); 2001

Li F and Liu XS. The status and development pattern of urban forest in China. Forestry Science and Technology Management (in Chinese) 2002;4:16-18

Li F and Wang RS. Evaluation, planning and prediction of ecosystem services of urban green space: $A$ case study of Yangzhou City. Acta Ecologica Sinica (in Chinese) 2003;23(9):1929-36

Luttik J. The value of trees, water and open space as reflected by house prices in the Netherlands. Landscape and Urban Planning 2000;48:161-7

Ma SJ and Wang RS. Social-economic-natural complex ecosystem. Acta Ecologica Sinica (in Chinese) 1984:4(1):1-9

Polansky C. Participatory forest management in Africa: lessons not learned. The International Journal of Sustainable Development and World Ecology 2003; $10(2): 109-18$
Rydberg D and Falck J. Urban forestry in Sweden from a silvicultural perspective: a review. Landscape and Urban Planning 2000;47:1-18

Savard J-PL, Clergeau P and Mennechez G. Biodiversity concepts and urban ecosystem. Landscape and Urban Planning 2000;48:131-42

Schell LM and Ulijaszek SJ. Urbanism, health and human biology in industrialized countries. London: Cambridge University Press; 1999:59

Shafer C. US National park buffer zones: historical, scientific, social, and legal aspects. Environmental Management 1999;23(1):49-73

Tarrant MC and Cordell HK. Amenity values of public and private forests: examining the value attitude relationship. Environmental Management 2002;30(5):692-703

Tyrv nen L. The amenity value of the urban forest: an application of the hedonic pricing method. Landscape and Urban Planning 1997;37:211-22

Wang ML. Research and development of urban forest. Forestry science (in Chinese) 1995;31(5):460-6

Wang RS, Chi J and Ouyang ZY. Eco-integration for sustainable development of middle and small sized towns. Beijing: Meteorologic Press (in Chinese); 2001: 31

$\mathrm{Wu}$ W. Development countermeasures of 'urban forest' in Tianjin. Tianjin Agronomy Transaction (in Chinese) 1994;3:33-9

Ye W. Discussion of several problems of urban forest planning and construction (continued). Guangdong Forestry (in Chinese) 1997;2:29-30

Zhang H. Green city is more green. China Forestry (in Chinese) 1997;7:18-19

ZhangJG. Modern forestry theory. Beijing: China Forestry Press (in Chinese); 1996: 222-31 